\title{
Hearth and Home in the Middle Pleistocene
}

\author{
STEVEN L. KUHN, School of Anthropology, University of Arizona, Tucson, \\ AZ 85721, USA. Email: skuhn@email.arizona.edu \\ MARY C. STINER, School of Anthropology, University of Arizona, Tucson, \\ AZ 85721,USA.Email: mstiner@email.arizona.edu
}

\begin{abstract}
The way in which humans organize their social and family lives is a defining feature of our species. Base camps, places to which food is carried and shared, and where many other activities occur, are central features in the lives of hunter-gatherers. Paleoanthropologists have been occupied with the search for base camps/home bases among early hominins for decades. Evidence now suggests that this essential feature of human life emerged in the Middle Pleistocene by around 400,000 years ago in the stem lineage that gave rise to Neanderthals and anatomically modern humans. Choices of where to live, the organization of stone tool making, butchery patterns, and widespread evidence of controlled use of fire around this time suggest a profound reorganization of the socioeconomics of daily life. These Middle Pleistocene campsites may not have functioned in exactly the same ways as those of more recent periods. They nonetheless set the stage for the evolution of many fundamental human tendencies and behavioral institutions.
\end{abstract}

Key words: Middle Pleistocene, Acheulo-Yabrudian, Levant, home bases, fire, sharing

Humans are animals, but of course very special animals. Identifying what differentiates humans from other creatures, and especially from our closest biological relatives, is a pursuit that has occupied people for centuries. This kind of exercise is central to our image of ourselves as human beings. For scientists interested in human origins, this question is even more crucial because it helps us anticipate what we really need to explain.

In this paper we focus on human family life, and the extraordinary level of economic cooperation that defines it, as central elements in our unique adaptations. The evolutionary origins of the basic pattern of human family life can be traced back to nearly half a million years ago, to the forebears of both Neanderthals and Homo sapiens. This shift in human behavior is reflected in part by changes in how people organized themselves and their activities on ancient landscapes, and in particular the emergence of places that we might call basecamps or domestic spaces. We begin the paper by outlining the (recent) history of attempts by paleoanthropologists to define human uniqueness. We then summarize the evidence that leads us and others to suggest when hearth and home

Submitted August 9, 2018; accepted August 22, 2018; published online July 12, 2019. Journal of Anthropological Research (Fall 2019). (C) 2019 by The University of New Mexico. All rights reserved. 0091-7710/2019/7503-0001\$10.00 
became such an important selective domain in human evolution. After establishing the empirical framework, we turn to some of the consequences of this development.

\section{HUMAN UNIQUENESS}

As Robert Foley implied in the title of his 1987 book, Another Unique Species, uniqueness is not unique to humans. Each species is, by definition, at least slightly different from every other species. Humans stand out because we are uniquely concerned about our own uniqueness (we attribute this to a highly evolved state of consciousness), and because some evolved traits of our species have had profound consequences for the rest of life on earth.

There have been many attempts to identify central features of human uniqueness, some more successful than others (de Waal 2016). Some distinctive aspects of Homo sapiens have more limited consequences for the human condition today than they did in the past. Bipedal striding locomotion evolved only among the hominins, and it is central to our evolutionary story. But surely there is more to it than just how we locomote on the ground: at least we like to think that we are more than just teetering apes. Other features are clearly important in the contemporary world but are empirically elusive in the deep past. Symbolic language is a singular behavioral and cognitive feature of humans, and clearly a lynchpin of many of our most outstanding features as a species. The problem is that language is remarkably difficult to study in periods before people began to record their ideas on durable media, whether it be pictographs or writing.

The apparent uniqueness of some other human traits disappears the more we learn about other animals. Tool use-once considered the exclusive domain of humans-is now known to be widespread in the animal world, common among primates, birds, and even mollusks (Bentley-Condit and Smith 2010; Seed and Byrne 2010; Shumaker et al. 2011). Humans are certainly the most dedicated and proficient tool-makers on earth, but we are hardly the only animals to create material objects that help us get things done. More generally, niche construction, the reshaping of one's environment in ways that affect natural selection in the future, is widespread among animals (Laland et al. 2000; Odling-Smee et al. 2003). We have also come to realize that carnivory, and hunting of mammals in particular, is not unique to humans among primates, even among the hominids (Stanford 1998; Teleki 1973; Tennie et al. 2014). Though meat eating is an important part of the story of how we got to be the way we are (Foley 2001; Stanford 1998; Stiner 2002), it is only part of the story.

Another, less tangible but crucial aspect of the human condition is our unique socioeconomic arrangements. Great apes and other primates exhibit many complex social behaviors that can seem very "human" to us. Nonetheless their social worlds, and the interface between the social and economic realms, are very different from those of any extant humans. Most importantly, human beings cooperate economically as well as socially in ways that are almost entirely alien to our primate relatives (Bowles and Gintis 2011; Tomasello 2009). In fact, early humans behaved more like social carnivores in regard to cooperative meat acquisition and food transport and sharing (Stiner 
2002). Humans pool labor, and the fruits of their labor, to an extraordinary degree. Although members of a family or other social unit may forage independently, and may even forage for different kinds of foods, they routinely share the products of their efforts with kin and non-kin alike. Sharing of food is quite rare in the primate world, yet it is utterly fundamental to human life just about everywhere one looks.

Almost 40 years ago, Owen Lovejoy and Glynn Isaac, a physical anthropologist and an archaeologist, respectively, proposed that human family life, cooperation, and complementary roles of males and females were critical but largely unexplored themes in early human evolution. They made rather similar arguments in papers published a few years apart (Isaac 1978; Lovejoy 1981). Using information from (then) recent studies of extant hunter-gatherers and nonhuman primates, both scholars made the following points: First, resource sharing is the basis of all human societies, but nonhuman primates seldom if ever share food, or anything else. Second, even very small-scale human societies are characterized by a certain level of specialization, distinct and complementary roles for males and females. In nonhuman primates, males and females follow very similar economic strategies - they feed themselves, and females feed dependent offspring exclusively through nursing. Third, males play a substantial role in caring for dependent offspring in many human societies, and they routinely collect food to be shared (though who gets it is another question). Among our closest nonhuman primate relatives, the great apes, males have relatively little to do with raising young apart from territorial defense, and they seldom if ever share food with their offspring.

All of this - the cooperation, the sharing, and the expanded roles that human males play in raising children-is essential to the cognitive development that defines Homo sapiens. It takes a village to raise a child, but it also takes a long time. Human children are extraordinarily altricial, meaning it takes them many years develop into adults physically, psychologically, and culturally. In small-scale, traditional economies the extraordinarily long period of juvenile dependency necessitates high levels of cooperation and resource sharing by both parents, by other children, and sometimes by other members of the society in question (Bogin et al. 2014; Burkart et al. 2009; Hrdy 2007; Kramer 2005). Human reproductive success is hugely facilitated by these cooperative arrangements and yet it remains a gamble for more than 15 years after the birth of a child.

Isaac, the archaeologist, also realized that the simple institution of the "base camp" is a key archaeological indicator of this uniquely human socioeconomic condition. For Isaac, and for us, a base camp is a single place in which people may sleep, eat, work, and socialize. It is a magnet on the landscape, and a place where other people can usually be found. Effective sharing and cooperation require that individuals get together in the same place. Without a stable base, a willing sharer could find themselves searching in vain for someone to share with. Unless other people are located in a limited number of predictable places at any given time, a would-be cooperator would find themselves without a cooperative partner. Consequently, the evolution of sharing-based, cooperative social groups would have a material correlate in the form of distinct kinds of 
locations, most importantly, places where people get together regularly and predictably to do all kinds of things. Archaeologists should expect to find telltale configurations of debris as signatures of these distinctive social and economic arrangements.

Given these ideas, the obvious question for a paleoanthropologist is when this unique pattern first appeared and in what forms. Isaac and Lovejoy both argued that these essential human features were in place quite early. Lovejoy (1981) implied that sharing and male provisioning were instrumental in the initial divergence of hominins from the apes and the evolution of bipedal locomotion. Isaac (1978) argued that base camps appeared somewhat later, and evidence for them could be found among what were at the time the world's earliest archaeological sites in Olduvai Gorge and Koobi Fora. What Isaac called "Type C" sites were characterized by associations of stone tools and toolmaking debris with fragmentary, generally incomplete remains of multiple animal carcasses. These sites demonstrated that hominins had repeatedly brought food and tool-making materials to the same place. These associations, Isaac argued, showed that such locations presented the most essential features of what anthropologists consider home bases among recent foragers.

Isaac's and Lovejoy's propositions quickly came under critical scrutiny. On the archaeological side of things, researchers questioned the origins of the bones found in the sites, whether there was really any evidence of sharing, and even whether the locations were physically or geologically appropriate as campsites (e.g., Binford 1981; Blumenschine 1991; Blumenschine et al. 1987; Potts 1984). In response to the controversy, many (including Isaac himself) reconsidered this interpretation, eventually opting for more neutral terms such as "central places" (Domínguez-Rodrigo and Pickering 2003; Isaac 1983; Rose and Marshall 1996) or "favored places" (Bunn 1991; Schick 1987) to refer to "Type C" sites. Inferences about fully developed patterns of sharing and division of labor were eventually abandoned by most researchers. Instead, "central places" were seen as fostering intensive interaction over transported food resources, setting the stage for the evolution of the familiar human patterns of resource pooling (Rose and Marshall 1996).

A more fundamental critique involved one of the basic premises of the "home base" hypothesis - namely, the role of males in provisioning offspring. In a series of highly influential papers, Kristen Hawkes and colleagues reexamined the assumption that male foragers hunted mainly with the goal to provide food for their own families. They concluded that patterns of meat sharing were inconsistent with a "family-first" interpretation. Instead, Hawkes and others argued that males engaged in risky but highreturn hunting of large animals in order to increase their own prestige within the community, affording them more mating opportunities and other benefits (e.g., Hawkes 1991; Hawkes and Bird 2002). Eventually they extended this argument to the early Pleistocene (O'Connell et al. 2002). Assertions about the actual benefits to males from sharing hunted meat have themselves been challenged (Gurven and Hill 2009; Marlowe 2003), but the notion that provisioning offspring was the only reason for hunting large animals in the past has largely been abandoned. 
As consequential as this ongoing debate is for understanding the evolution of human socioeconomic arrangements, it is important to emphasize that no one is skeptical about claims that hunter-gatherers, women and men alike, routinely bring the products of their foraging activities back to a central place to share it. What is in dispute are the proximate motivations and evolutionary explanations for this behavior. In rejecting Isaac's and Lovejoy's ideas about very early base camps, researchers lost sight of some of the central issues they had raised. Quite appropriately, a great deal of attention was subsequently focused on the question of how bones and artifacts came to be associated at certain locations during the early Pleistocene, and whether the associations were behavioral or geologic in origin (e.g., Bunn et al. 1980; Egeland 2008; Egeland et al. 2004; Schick 1987). Debates also shifted to whether early Pleistocene hominins obtained meat by hunting, by "active" or "confrontational scavenging, or by "passive" or late-stage scavenging (e.g., Blumenschine 1991; Blumenschine et al. 1987; Domínguez-Rodrigo and Pickering 2003; Domínguez-Rodrigo et al. 2007, 2010; Pickering 2013; Plummer 2004). Meanwhile the question of how and when the unique socioecology of humans evolved has largely disappeared from center stage. Since the early 1980s paleoanthropologists have engaged in curiously little analytical exploration of sharing and division of labor, although it has remained an important focus for human behavioral ecologists.

We propose that Isaac and Lovejoy were on the right track regarding the importance of food sharing and central places but they were wrong about the timing. A range of evidence emerging over the past 15 years leads to a new hypothesis that many essential features of the hominin socioeconomic niche emerged in the "mid-Middle" Pleistocene, beginning ca. 500-450 kya, in both Eurasia and Africa. A number of researchers find archaeological evidence that new kinds of sites and new ways of organizing activities on the landscape emerged around this time (Chazan 2009; Kuhn et al. 2018; Rolland 2004; Stiner et al. 2011). Important developments in animal exploitation and changes in the ways that lithic technologies were organized were intimately connected to changes in land use. There are also signs that hominins began to use fire in different ways and more habitually after 500 kya (Karkanas et al. 2007; Rolland 2000; Shimelmitz et al. 2014). We do not assert that the systems of sharing and division of labor so familiar among recent hunter-gatherers were fully developed at this early date. On the contrary, there is reason to think that, although Middle Pleistocene hominins were highly social and cooperative, they organized their sharing somewhat differently than contemporary foragers. However, the basic foundations of the typical hunter-gatherer pattern were in place in the form of residential camps by 450-400 kya.

\section{ARCHAEOLOGICAL SIGNATURES OF MIDDLE PLEISTOCENE BASE CAMPS}

In this section we summarize the various lines of evidence for important changes in hominin socioecology during the mid-Middle Pleistocene. We focus on one small region, the Levant. This region lies in the eastern Mediterranean basin and spans modern-day 
Lebanon, Syria, Jordan, and Israel. This is not the only place where important changes in human behavior unfolded during the period between 450 and 250 kya, nor did things necessarily change here earlier than everywhere else. Similar developments were occurring at more or less the same time in sub-Saharan Africa, Europe, and probably East Asia as well. We have chosen to concentrate on this area because it is well-studied and fairly small, with a substantial but manageable number of well-dated sites. Figure 1 shows the most important archaeological and fossil localities to be discussed below. Wellknown sites with substantial deposits dating to this period include Tabun cave, Qesem cave, Misliyah cave, and Zuttiyeh cave in Israel, and Dederiyeh cave, Yabrud Shelter I, and Hummal in Syria.

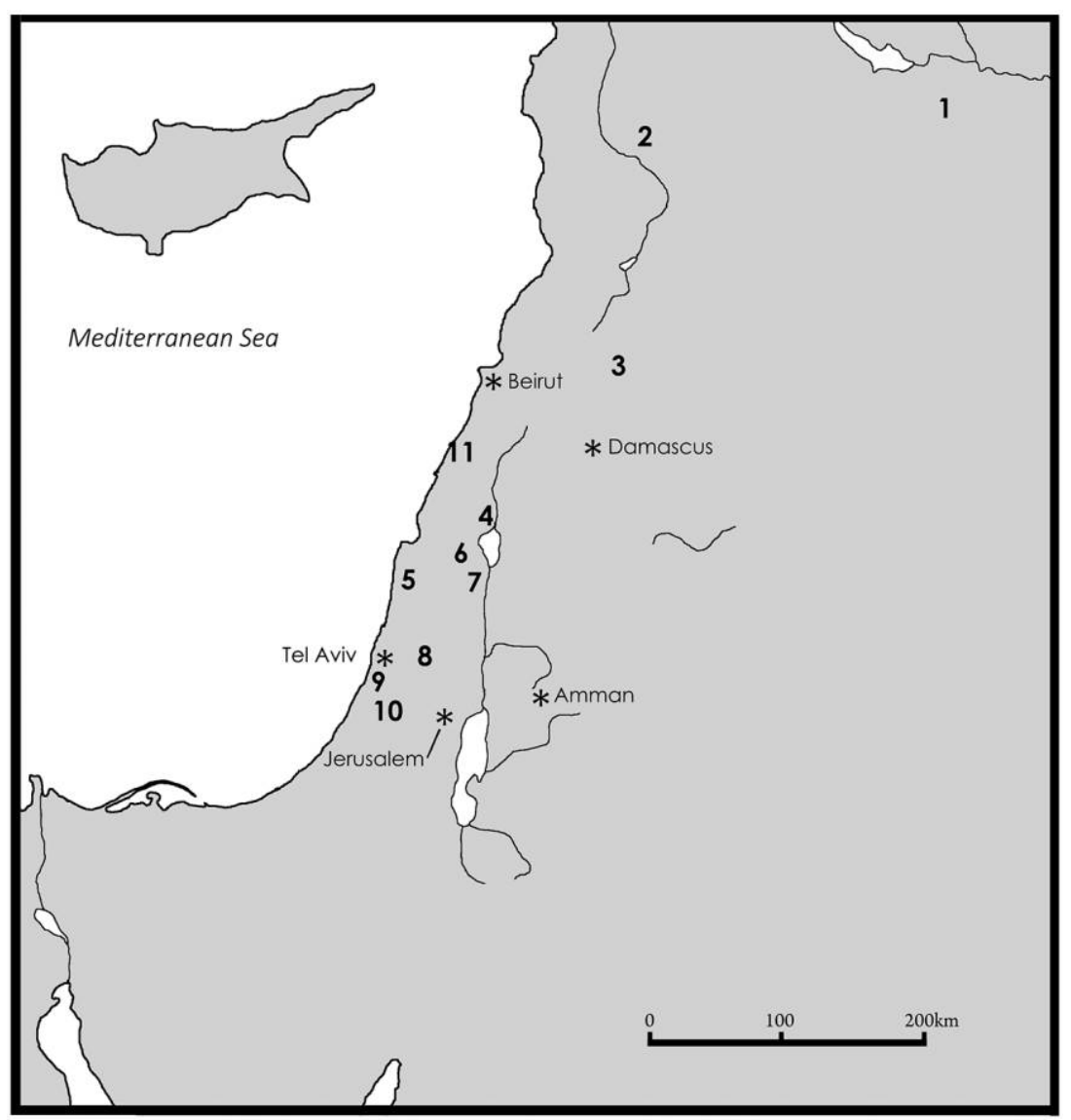

Figure 1. Map showing some of the Middle Pleistocene and earlier sites mentioned in the text. 1, El Kowm Basin; 2, Latamne; 3, Yabrud Shelter I; 4, Gesher Benot Ya'aqov; 5, Tabun and Misliya Caves; 6, Zuttiyeh; 7, 'Ubeidiya; 8, Qesem Cave; 9, Holon; 10, Revadim Quarry; 11, Adlun (after Sharon 2014). 
We are more concerned with evidence for behavior of hominins than with taxonomic distinctions, but some reference to the hominin populations of interest cannot be avoided. The mid-Middle Pleistocene was the time of Homo heidelbergensis, a poorly defined and somewhat controversial taxon that basically represents the ancestors of modern humans, Neanderthals, and other coeval populations. Other regional names for the same or very similar hominins include $H$. antecessor, $H$. rhodesiensis, and even late $H$. erectus. Their skulls were differently shaped from and more robust than those of recent humans, with somewhat smaller cranial capacities (ca. 1100-1200 cc), yet they contained large, complex brains by primate and earlier hominin standards. Their postcranial anatomy was much like ours, albeit more robust and rugged, and with locomotor stamina and efficiency equal or superior to the most athletic humans today (Harvati 2007; Mounier et al. 2009; Rightmire 2003; Stringer 2012).

Caves

Arguably the most visible archaeological development after 500 kya is a shift in land use to include new kinds of dwelling places. Caves came into widespread use for the first time, and the range of activities carried out in caves is distinctive. Archaeological localities dating to before 500 kya consist almost entirely of open-air sites, often kill/ scavenging/butchery locations typically situated near permanent or seasonal water sources. The best known examples include 'Ubeidiya (Bar-Yosef and Goren-Inbar 1993), Gesher Benot Ya'aqov (Goren-Inbar et al. 2000), and probably Latamne (Clark 1967, 1969). Artifact assemblages associated with large herbivore bones in these sites are characterized as early or middle Acheulean: they include large tools such as handaxes and cleavers along with small, rather informal flake tools. The sites may also contain traces of hominin activities not directly related to carcass butchery. The best-preserved and most intensively studied site is Gesher Benot Ya'aqov (GBY), which dates to the very beginning of the Middle Pleistocene. Evidence for use of fire and plants is documented at GBY (Alperson-Afil 2008; Goren-Inbar et al. 2004; Melamed et al. 2016). Yet most of what went on in mid-Middle Pleistocene sites seems to have been functionally and/or spatially associated with the exploitation of carcasses of medium to large game animals.

The onset of intensive and regular use of caves and rockshelters around $450 \mathrm{kya}$ is important. At least one site, Tabun, may contain debris from occupations older than this, but there are a great many more caves with occupations dating to 450-250 kya. These occupations were not just numerous: many of these places held their importance to hominins for tens of thousands of years. Deposits in Tabun cave that date to the period in question (units X-XIV in Jelinek's stratigraphic scheme) occupy around six vertical meters of the total sequence (Jelinek 1982; Jelinek et al. 1973). The archaeological accumulations at Qesem cave span a similar temporal range (ca. 400-200 kya) and are around $7.5 \mathrm{~m}$ thick (Gopher et al. 2005). Deposits in Yabrud Shelter 1 with similar artifact assemblages have a thickness of $10 \mathrm{~m}$ or more (Rust 1950; Solecki and Solecki 1986). The densities of archaeological materials fluctuate within these long 
stratigraphic sequences, but there can be no doubt that hominins visited these locations again and again over hundreds of millennia. Open-air sites are also known from this period, but they yield very different kinds of archaeological materials (see below).

Recognizing and interpreting these shifts in site use and contents requires some unpacking of the observed archaeological patterns. Like a puzzle or repeated overlay of a simple printed pattern, the composite has a different look than the individual pieces of which it is constituted. The ways these composites were compiled or formed-and the repetition, or not, of certain patterns of behavior - provides important clues as to how the land-use strategies of the mid-Middle Pleistocene may have differed from later periods. The tendency to reuse places within and across hominin lifetimes is an important development in itself. The Middle Pleistocene archaeological horizons in caves such as Tabun generally are palimpsests of many short visits (Kuhn and Clark 2015), marked by notable redundancy in lithic assemblages. In contrast, deeply stratified Middle Paleolithic caves such as Hayonim and Kebara or the upper layers at Tabun, show lessconstrained patterns of variation and clearer extremes in the nature and duration of episodes of occupation (Meignen et al. 2006; Speth and Clark 2006; Stiner 2013).

\section{Technological Diversity}

In the period between $450 \mathrm{kya}$ and $250 \mathrm{kya}$, hominins in the Mediterranean Levant created a diverse range of lithic artifacts and assemblages, and the most diverse stone artifact assemblages are found in caves. The terms Acheulo-Yabrudian complex or Mugharan tradition (Jelinek 1990) are typically used to refer to these Levantine midMiddle Pleistocene assemblages as a group. Three main assemblage types have been identified-Yabrudian, Amudian, and Acheulean or Acheulo-Yabrudian—although a surprising number of other names have been used in the past (Shimelmitz and Kuhn 2017). Each assemblage type or facies is characterized by a distinctive mix of artifact forms (Figure 2). Yabrudian assemblages are known for high frequencies of heavy "scrapers," many with Quina retouch. Amudian assemblages are noted for the presence of numerous delicate tools made on blades struck from simple prismatic cores. Not surprisingly, the Acheulean facies is distinguished by relatively large numbers of bifacial handaxes. It is important to emphasize that the differences among these three variants are largely a matter of varying frequencies of the same set of key elements. The majority of Levantine cave site assemblages dating to this period contain at least a few heavy scrapers and handaxes: they are just more abundant in Yabrudian and Acheulean assemblages, respectively. Blade production is less ubiquitous overall, but many assemblages that would not be classified as Amudian contain a few well-made blades or blade cores.

The mid-Middle Pleistocene also sees considerable diversification in the strategies for making artifacts and managing raw materials. The small tools, and the variety of edges they provide, seem to have been intended for different tasks, based on use-wear evidence and design. Microscopic use-wear traces on blades from Qesem cave, for example, show that they were used mainly for cutting meat and other soft materials (Lemorini et al. 2006). The slender, delicate blade tools also had short life histories: 

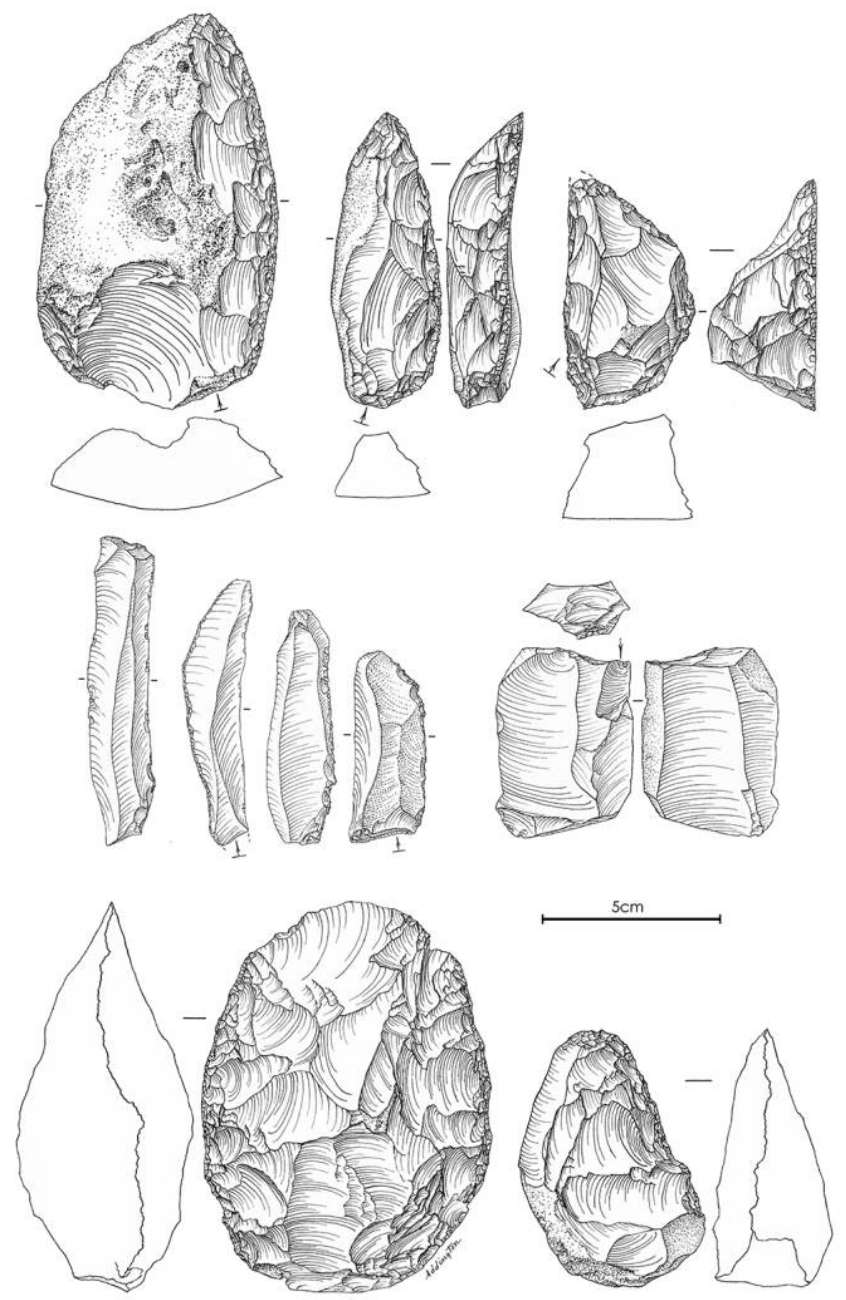

Figure 2. Typical artifacts of the Acheulo-Yabrudian or Mugharan tradition, from Tabun Cave. Top row, heavy sidescrapers; middle row, blades and blade core; bottom row, bifacial handaxes. (Illustrations by Lucille Addington, courtesy of Arthur Jelinek)

they were typically made, used, and discarded on the spot (Barkai et al. 2009). Handaxes, in contrast, seem to have had longer and more varied life histories: these artifacts were moved around extensively and seldom were discarded in the places that they were made (Kuhn and Clark 2015; Shimelmitz et al. 2017). The thick scrapers from Acheulo-Yabrudian assemblages were used on a variety of materials (Lemorini et al. 2016; Solodenko et al. 2015). The extensive reduction and reworking of many scrapers also indicates that they had long life histories. 
Interestingly, the kinds of artifacts and assemblages that define the AcheuloYabrudian, particularly the blades and heavy scrapers, are seldom found in open-air sites, not even in those located rather near to cave sites. With the exception of a series of intensively frequented spring mounds in the arid interior of Syria (Copeland and Hours 1983; Le Tensorer 2005), all known Acheulo-Yabrudian assemblages come from caves and rockshelters. Mid-Middle Pleistocene open-air sites have technological profiles more like older sites such as GBY. The quasi-contemporaneous open sites of Holon (Chazan and Horowitz 2007; Porat et al. 1999) and Revadim (Marder et al. 2008,2011 ) are defined by the presence of large animal carcasses, including remains of megafauna, and Acheulean assemblages with bifacial handaxes alongside small flake tools. Other kinds of open sites, such as lithic workshops and extensive accumulations of handaxes (Bar-Yosef 1994; Barkai et al. 2002), are also known in the Mediterranean Levant but as yet their ages are not well established.

\section{Hunting and Transporting Food}

The faunal records of caves and open-air sites of the mid-Middle Pleistocene also differ from what came before. Megafauna-rhinoceros, elephant, hippopotamus-were exploited on the coastal plain. Bone specimen counts (NISP) are low in these sites, and megafauna comprise a large proportion of the identified remains (Table 1). It is difficult to determine whether these megafauna species were hunted or scavenged and how much of the carcass was available to early humans, but their meat was exploited at the open sites of Revadim (Marder et al. 1999, 2008) and Holon (Chazan and Horowitz 2007), among others.

Megafauna remains are also present in mid-Middle Pleistocene cave sites such as Qesem (Stiner et al. 2011) and Adlun (Garrard 1983), but they constitute only a small minority of the remains (Table 1), even in terms of biomass. Moreover, the megafauna remains in cave sites are often teeth and isolated smaller bones. The peculiar focus on teeth may better reflect interest in their material properties rather than food. One of us (MS) has observed that some rhino teeth from Qesem cave and elsewhere were flaked in an expedient manner (unpublished data). The high energetic cost of transporting very heavy bones may help to explain the paucity of megafauna remains in caves, but this consideration takes a back seat to the repetitive dominance and sheer numbers of medium-sized and large ungulates in caves. Very different to most open sites, where one-off or rare events may be represented, the quantities of anthropogenic faunal remains in some caves indicate long accumulation times that spanned many separate visits spread over decades, centuries, or millennia. Staple meat sources for hominin populations are better represented as a result, and these staples were not megafauna but rather deer (fallow deer, red deer) and bovids such as aurochs.

The faunal evidence tells us that the staple prey species were obtained by hunting. Ungulate mortality patterns are biased to prime adult individuals, body part representation indicates that the hominins were not picking through another predator's 
Table 1. Megafauna and ungulate frequencies (NISP) in selected later Middle Pleistocene archaeological open-air and cave sites in the southern Levant.

\begin{tabular}{|c|c|c|c|c|c|c|c|}
\hline Taxon & $\begin{array}{c}\text { LP } \\
\text { Evron } \\
\text { (open) }\end{array}$ & $\begin{array}{c}\text { LP } \\
\text { Revadim } \\
\text { (open) }\end{array}$ & $\begin{array}{c}\text { LP } \\
\text { Holon } \\
\text { (open) }\end{array}$ & $\begin{array}{l}\text { late LP } \\
\text { Adlun } \\
\text { (cave) }\end{array}$ & $\begin{array}{c}\text { late LP } \\
\text { Qesem } \\
\text { (cave) }\end{array}$ & $\begin{array}{c}\text { early MP } \\
\text { Adlun } \\
\text { (cave) }\end{array}$ & $\begin{array}{c}\text { early MP } \\
\text { Hayonim } \\
\text { (cave) }\end{array}$ \\
\hline \multicolumn{8}{|l|}{ Elephantidae } \\
\hline Palaeoloxodon antiquus & & 23 & 120 & & & & \\
\hline Elaphus sp. & 1 & & & & & & \\
\hline Stegodon sp. & 10 & & & & & & \\
\hline \multicolumn{8}{|l|}{ Hippopotamidae } \\
\hline Hippopotamus sp. & 7 & & & & & & \\
\hline Hippopotamus amphibious & & & 29 & & & & \\
\hline \multicolumn{8}{|l|}{ Rhinocerotidae } \\
\hline Dicerorhinus hemitoechus & & & & & 37 & & 2 \\
\hline Dicerorbinus cf. mercki (?) & & & & 8 & & & \\
\hline \multicolumn{8}{|l|}{ Equidae } \\
\hline Equus caballus & & & & & 119 & & 10 \\
\hline $\begin{array}{c}\text { Equus hemionus/ } \\
\text { hydruntinus }\end{array}$ & & & & & 12 & & 12 \\
\hline Equus sp. & & 1 & & 19 & & & \\
\hline \multicolumn{8}{|l|}{ Suidae } \\
\hline Kolpochoerus evronensis & 2 & & & & & & \\
\hline Sus scrofa & & 1 & 2 & 4 & 55 & 4 & 176 \\
\hline \multicolumn{8}{|l|}{ Cervidae } \\
\hline Cervus elaphus & 1 & 4 & 3 & & 28 & 2 & 155 \\
\hline Dama mesopotamica & & 2 & 247 & 123 & 2103 & 93 & 1178 \\
\hline Capreolus capreolus & 3 & 0 & & 1 & 2 & $?$ & 11 \\
\hline \multicolumn{8}{|l|}{ Bovidae } \\
\hline Bos primigenius & 7 & 1 & 162 & 89 & 200 & 8 & 281 \\
\hline Alcelahus (?) sp. & 2 & & & & & & \\
\hline Capra aegagrus & & & & & 3 & 1 & 8 \\
\hline Gazella gazelle & 1 & & 7 & 1 & & 36 & 1912 \\
\hline TOTAL NISP & 34 & 32 & 570 & 245 & 2559 & 144 & 3745 \\
\hline
\end{tabular}

Notes: (NISP) number of identified faunal specimens; (LP) Lower Paleolithic; (MP) Middle Paleolithic; (open) open land site; (cave) stratified cave site. Data sources: Evron Quarry, Tchernov et al. 1994; Revadim, Marder et al. 1999; Holon, Chazan and Kolska Horwitz 2007; Adlun cave, Garrard 1983; Qesem cave, Stiner et al 2011; Hayonim cave, Stiner 2005. 
leftovers, and the record of tool marks indicates ample access to and removal of flesh from carcasses. Qesem cave provides definitive evidence of prime-age-biased hunting of fallow deer back to about 400 kya (Stiner et al. 2011). Tabun cannot be compared on this question due to spotty faunal preservation, but similar patterns have been documented in Germany at the site of Wallertheim (Gaudzinski 1995). The trend toward habitual (albeit mild) focus on prime adult ungulate prey is ecologically unique to Paleolithic and recent humans, and it differs from the prey selection patterns of canids, felids, and hyaenids (Stiner 1990). We do not know just when prime-age-biased prey selection emerged, but it probably happened sometime between 1 million and 500,000 years ago.

The occupants of Qesem cave, the only Acheulo-Yabrudian site in the region for which detailed taphonomic studies have been published, often delayed their consumption of some meaty and marrow-rich foods until these items could be moved to the cave (Stiner et al. 2011). Their decisions about which body parts to bring back to the cave depended on food value, weight, and travel times between kill sites and the cave. Upper and lower limb segments are typically high-value parts even after some of the flesh has been removed, because they contain large stores of medullary marrow if the prey animal was well nourished at the time of death. The implements used for extracting nutrients from carcasses were pounding tools (a possible use for spheroids), cutting and scraping tools, and fire. The greater the distance between kill sites and camp, the greater the likelihood that hominins would leave low-utility parts such as the axial column behind. In addition to limb bones, skulls were routinely carried to caves because their nutritional yield is enhanced by roasting on the coals of a fire.

\section{Fire and Shelter}

Cave sites and novel artifact assemblages of the mid-Middle Pleistocene are intimately associated with fire. These cases do not represent the oldest use of fire, which may date back to 1 million years ago in southern Africa (Berna et al. 2012) and 780 kya at Gesher Benot Ya'aqov (Alperson-Afil 2008). However, mid-Middle Pleistocene cave occupations in the Levant evidence frequent, repeated use of fire. The traces of fire occur as patches of burned sediment or charred bones and heat-damaged artifacts.

In Tabun cave, the presence of fire is inferred from the densities of burned lithic artifacts (Shimelmitz et al. 2014); bone preservation is too uneven in this site to be considered. In Qesem cave, one large, semi-intact combustion feature containing preserved wood ash occurs midway through the stratigraphic sequence (Karkanas et al. 2007; Shahack-Gross et al. 2014). However, a more complete picture of fire use is gained from mapping the heterogeneous distributions of burned bone splinters (Stiner et al. 2011), which are present from nearly the beginning of the cultural sequence to its end. Burning damage occurs on as much as $91 \%$ of the unidentified bone splinters within the concentrations, and the fact that up to $16 \%$ of specimens are calcined indicates intense, prolonged heating. The frequent repetition of burning damage through the deep stratigraphic sequences of the two cave sites tells us that (a) fire-making was 
a habitual and widely repeated activity and $(b)$ these places were of perennial importance to hominins in the region. Sequences at both sites show a distinct uptick in the frequency of burning damage sometime around 350-325 kya (Karkanas et al. 2007; Shimelmitz et al. 2014; Stiner et al. 2011).

An important question to ask at this point is whether the strong connection that we perceive between caves and fire in the mid-Middle Pleistocene is an artifact of better preservation conditions in caves than in open-air sites, rather than a signal of new forms of behavior. If archaeologists relied solely upon intact wood ash to infer fire use by hominins, then surely caves are better preservation environments than open sites. However, burned bones and especially burned artifacts can be preserved in large numbers in any kind of site, and it is only in caves that they occur with such regularity during the mid-Middle Pleistocene in the Levant.

Zooarchaeological data also provide ample evidence for cooking, deferred consumption, and presumably sharing of meat at Qesem cave (Stiner et al. 2011). The frequency of burning damage on ungulate bones differs a great deal by skeletal element, and it is most common on major limb bones such as the femur, humerus, and tibia. The intensity of burning damage on these limb bones is higher as well. To interpret the evidence one must first recognize that there is no simple relationship between cooking meat and burning of bones. For a bone to burn, it must be exposed directly to fire; otherwise the moist soft tissues that normally surround a bone cool it and prevent burning. Yet leg bones in Qesem cave are often burned, and many are heavily burned. Such damage implies that the bones were stripped of most their soft tissue before being heated for the last time, either because the bones were heated just prior to marrow extraction (a common practice among recent foragers) or because the fragments resulting from marrow processing were discarded around hearths and burned accidently. Both of these scenarios probably apply to Qesem cave, but the nonrandom patterns of burning show that the former was important. There are no indications of burning bones as fuel.

Ungulate heads were usually carried to caves along with limb bones during the Paleolithic, and the mid-Middle Pleistocene assemblages from Qesem are no exception in this regard. The goal of bringing ungulate heads to caves would be to roast them (and perhaps to use the brains for waterproofing hides). Head parts are structurally complex and difficult to process raw. In the absence of cooking pots, roasting is the most efficient way to extract their food value. The low rate of burning on head parts in Qesem (and other sites) may be because the tissue covering the skull was left intact and shielded the fresh bones and teeth from the hot coals of hearths. Tortoise (Testudo) remains also show a strong association with fire in Qesem cave, with 19\% of their bones burned on average. Burning is most common on the plastron or belly plate of the shell, consistent with roasting the animal whole.

Cut marks are very common on the ungulate bones from Qesem, mainly on limb shafts. The cut marks are peculiar for their rather "disorderly" orientations in comparison with Middle Paleolithic and later periods. Whether processed by hunter-gatherers 
or livestock herders today, a carcass is normally butchered and dismantled by just one or a few skilled persons, and the cut marks (to the extent that tool edges ever meet bone) will be fairly well aligned on bone surfaces as a result. In the Qesem faunas crossed marks occur with surprising frequency. The crossed marks are not the result of random geological scratching and in fact are concentrated on just a few meat-bearing elements. The chaotic orientations of the Qesem cut marks indicate a wider range of butchering postures, or ways of holding a body part while cutting away meat and other connective tissue. Moreover, the cut marks generally are simple types with V-shaped cross-sections made mainly by slicing motions. One can propose on the basis of these observations that the Qesem marks reflect less formality, or skilled control, during meat removal. A greater diversity in human body positions while cutting flesh might reflect more hands removing tissue from any given limb bone, rather than receiving shares that were funneled through the butchering work of a few. This pattern contrasts strongly with later Middle and Upper Paleolithic faunas of the region (Stiner et al. 2011). A simpler or less evolutionarily derived pattern of meat consumption around hearths seems to have existed during the latter half of the Middle Pleistocene.

\section{DOMESTIC SPACE AS A NOVEL COEVOLUTIONARY FORUM}

Paleoanthropologists have recognized for decades that important evolutionary developments in hominin physiology and behavior took place during the Middle Pleistocene. Over the $40+$ years that have elapsed since the publication of Butzer and Isaac's landmark volume After the Australopithecines (Butzer and Isaac 1975), the full scope of what happened during this interval of geological time has come into clearer focus. In addition to the developments discussed specifically in this paper, the second half of the Middle Pleistocene saw the origins of Levallois methods and other elaborate ways of manufacturing stone tools (Adler et al. 2014; White and Ashton 2008). The use of pigments, perhaps as a signaling medium, also emerged at roughly this time, first in Africa (Watts et al. 2016) and, it now appears, somewhat later in Eurasia (Roebroeks et al. 2012). Here we have chosen to focus more specifically on the socioeconomics of hominin life.

The strong connection between controlled use of fire and caves, with associated developments in technology and carcass transport and processing, signals significant changes in the ways hominins organized their lives on landscapes, and the kinds of activities that took place in different locations. Starting around $450 \mathrm{kya}$, hominins began to partition their activities more strategically in space. They began to spend appreciable amounts of time in places where food did not occur naturally. Caves and rockshelters can be fine places to sleep and find protection from the elements, once other residents have been evicted (Straus 1979). But there is little if anything for hominins to eat in caves, and there may not be much more in the immediate surroundings. Food and other resources must be found elsewhere. Rather than moving to concentrations of food, Mid- 
dle Pleistocene hominins had begun to create, and systematically reoccupy, places on the landscape which had to be provisioned with food.

The distinct life histories of blades, scrapers, and handaxes in mid-Middle Pleistocene sites are further evidence for this differentiated land use. Technology served distinct needs in different parts of hominin territories. Some artifacts were made for immediate use and rapid discard (blade tools), whereas others (handaxes) were carried along as the hominins moved from place to place. Some kinds of artifacts (blades and heavy scrapers) were deposited almost exclusively in natural shelters, whereas others (handaxes) could be dropped almost anywhere. These contrasting strategies of artifact production and use show that tools were serving different needs in different places, consistent with other signs of a more strategically differentiated way of using the landscape.

In sum, what we seem to have in the Mediterranean Levant (and probably elsewhere) starting around 450 kya is the emergence of true domestic spaces (Chazan 2009; Rolland 2000, 2004). By domestic space we mean protected locations where many activities related to food sharing and cooperative child rearing took place. These places - whether one wants to call them residential camps or the first home bases- had become distinct spatially from the locations where food and other resources were procured. They would have been attractive due to some natural affordances, such as caves, rockshelters, and springs: but these same affordances were not as attractive to earlier hominins. What really made them magnets for individuals hominins was the presence of other individuals and the resources they brought with them.

The emergence of residential campsites might not seem so riveting a theme as the first stone tools, the first fire, or the earliest art, but its effects were lasting and profound. The rise of hearth-centered base camps is a niche-constructing behavior with remarkable consequences (Stiner and Kuhn 2016). These spaces were created by hominin actions in combination with natural affordances. They fundamentally changed the calculus of resource acquisition and social interaction. More and more, hominins were coevolving with the world that they modified. This coevolutionary process altered the conditions of selection for descendants, and particularly within the confines of domestic spaces. Granted, there is good reason to think that these very early residential campsites were not quite the same as those of succeeding Paleolithic periods; sharing of meat, for example, seems to have been organized in ways different from what modern humans or even Neanderthals practiced. And although there was a definite increase in fire use around $350 \mathrm{kya}$, fire records did not become ubiquitous until after about 250,000 years ago (Roebroeks and Villa 2011; Rolland 2004; Gowlett 2016). Nonetheless they mark a real alteration in the trajectory of hominin behavioral evolution.

These sorts of domestic spaces or camps fundamentally changed the evolutionary arenas for social interaction. Places where individuals congregated and to which resources were brought held great potential for mining social resources (Dunbar 2003; Foley and Gamble 2009; Gamble 1999). In addition to offering many physical benefits, we can think of base camps as new kinds of resource patches created by the hominins 
themselves. In contrast to natural patches of food or stone, such artificial concentrations of food and other resources in camps could only be accessed through a web of social interactions. In this way, temporary protected domestic spaces set the stage for other crucial evolutionary developments that define the recent human species.

At the center of this new kind of site were the hearths that lent greater reliability and versatility to camp function. The multiple conveniences of fire also created irresistible interaction bubbles wherein a host of new selection constraints could operate on hominin society (Dunbar 2003; Preece et al. 2006; Wrangham and Carmody 2010). The roles that individual hominins could play in creating hearth-centered camps entailed much more than just the knowledge of how to make fire. Fires must be maintained in order to form a hub for planning and carrying out other economic and social activities. Although acts of sharing at these locations can be difficult to demonstrate directly, it would be nearly impossible to avoid sharing in such confined, well-stocked social spaces. Of course, the act of gathering around fireplaces can provoke tensions as well as create opportunities. The benefits of cooperatively maintained hearths, not least for processing prey carcasses, nonetheless clearly outweighed any new costs to aggregating again and again in camps.

The appearance of these new fora for social interaction might even have been a trigger for the most recent stages of encephalization in hominins. Much of the late expansion of the hominin brain occurred in the neocortex (de Souza and Cunha 2012; Weaver 2005), an area important to planning, logic, emotional control, and other advanced cognitive functions. As noted by R. Dunbar (2003), this part of the brain is critical to hominins' ability to empathize and reliably model the intentions of other individuals in the social group, and a cognitive requirement for high-order cooperation. It is useful in this light to consider later social developments linked directly to base camp life. By Marine Isotope Stage 5 (after 120 kya), hearth-centered base camps had become a given. Shortly thereafter we find evidence of costly acts of social caring in the form of extended life-spans of physically compromised adults. We also see expanded recruitment of material culture into hominin signaling strategies, first pigments and later beads. All of this attests to increasingly intensive social interaction and creation of identities independent of specific individuals. Perhaps most affecting to recent human observers, these oftused residential camps were also the setting in which Middle Paleolithic burial practices first appeared (reviewed in Stiner 2017). By the Upper Pleistocene, the campsite phenomenon that began in the mid-Middle Pleistocene had become the "persistent" places that ultimately could serve as metaphors of identity, social affinity, and even commemoration (Gamble and Roebroeks 1999).

\section{NOTES}

This article derives from the XLVI Journal of Anthropological Research Distinguished Lecture, which we presented in Albuquerque in March 2018. This was the first in a series of lectures by University of New Mexico Anthropology PhD alumni on the occasion of the department's 90th anniversary. It was a great honor to be invited to pre- 
sent a lecture in this context, and we are very grateful to Prof. Lawrence Straus and the $J A R$ staff for making our visit to our alma mater so enjoyable and stimulating. We were fortunate enough to have done our graduate work at UNM during a period when the department housed several leading scholars in Paleolithic archaeology human evolution research, including Prof. Straus, Prof. Eric Trinkaus, the late Prof. Lewis Binford, and the late Prof. Henry Harpending. Our interactions with these brilliant researchers and teachers had a profound effect on our careers and our development as human beings. We also want to thank Prof. Arthur Jelinek, who encouraged SK to study materials from his excavations at Tabun cave. Working with the Tabun collections, and our discussions with Art about early hominins and their stone tools, helped shape our thinking about the Middle Pleistocene in the Levant. A good deal of what SK thinks about Middle Pleistocene technology has also emerged from his collaboration with Dr. Ron Shimelmitz. We should also acknowledge Drs. Avi Gopher and Ran Barkai, who invited MS to study the fauna from Qesem Cave.

1. Some chimpanzee groups do seem to "share" food, but only meat from hunted monkeys. It is difficult to distinguish sharing from tolerated theft or other forms of pseudo-cooperation among chimpanzees (Wood and Gilby 2017; Tennie et al. 2014). Moreover, chimpanzees do not carry food to central locations so that others will have access to it. They share it—or give it up to persistent scroungers—on the spot.

\section{REFERENCES CITED}

Adler, Daniel S., K. N. Wilkinson, Simon Blockley, D. F. Mark, Ron Pinhasi, B. A. SchmidtMagee, Samvel Nahapetyan, et al. 2014. Early Levallois technology and the Lower to Middle Paleolithic transition in the southern Caucasus. Science 345 (6204):1609-13.

Alperson-Afil, Nira. 2008. Continual fire-making by hominins at Gesher Benot Ya'aqov, Israel. Quaternary Science Reviews 27(17-18): 1733-39.

Bar-Yosef, Ofer. 1994. The Lower Paleolithic of the Near-East. Lournal of World Prehistory 8(3): 211-65.

Bar-Yosef, Ofer, and Naama Goren-Inbar. 1993. The lithic assemblages of 'Ubeidiya: A Lower Paleolithic site in the Jordan Valley (Qedem). Jerusalem: Institute of Archaeology, Hebrew University.

Barkai, Ran, Avi Gopher, and Philip C. La Porta. 2002. Palaeolithic landscape of extraction: Flint surface quarries and workshops at Mt. Pua, Israel. Antiquity 76(293):672-80.

Barkai, Ran, Cristina Lemorini, Ron Shimelmitz, Z. Lev, Mary C. Stiner, and Avi Gopher. 2009. A blade for all seasons? Making and using Amudian blades at Qesem Cave, Israel. Human Evolution 24(1):57-76.

Bentley-Condit, Vicki, and E. O. Smith. 2010. Animal tool use: Current definitions and an updated comprehensive catalog. Behaviour 147(2):185-221.

Berna, Francesco, Paul Goldberg, Liora Kolska Horwitz, James Brink, Sharon Holt, Marion K. Bamford, and Michael Chazan. 2012. Microstratigraphic evidence of in situ fire in the Acheulean strata of Wonderwerk Cave, northern Cape Province, South Africa. Proceedings of the National Academv of Sciences (USA) 109(20):E1215-20.

Binford, Lewis R. 1981. Bones: Ancient men and modern myths. New York: Academic Press. 
Blumenschine, Robert J. 1991. Hominid carnivory and foraging strategies, and the socio-economic function of early archaeological sites. Philosophical Transactions of the Roval Societv of London B: Biological Sciences 334(1270):211-21.

Blumenschine, Robert J., Henry T. Bunn, Valerius Geist, Fumiko Ikawa-Smith, Curtis W. Marean, Anthony G. Payne, John Tooby, and Nikolaas J. van der Merwe. 1987. Characteristics of an early hominid scavenging niche [with Comments and Reply]. Current Anthropology 28(4):383-407.

Bogin, Barry, Jared Bragg, and Christopher Kuzawa. 2014. Humans are not cooperative breeders but practice biocultural reproduction. Annals of Human Bioloog 41(4).368-80.

Bowles, Samuel, and Herbert Gintis. 2011. A cooperative species: Human reciprocity and its evolution. Princeton, NJ: Princeton University Press.

Bunn, Henry T. 1991. A taphonomic perspective on the archaeology of human origins. $\underline{A n-}$ nual Review of Anthropology 20(1):433-67.

Bunn, Henry T., John W. K. Harris, Glynn Ll. Isaac, Zefe Kaufulu, Ellen M. Kroll, Kathy D. Schick, Nicholas Toth, and Anna K. Behrensmeyer. 1980. FxJj50: An early Pleistocene site in northern Kenya. World Archaeolooy 12(2):109-36. doi:10.1080/00438243.1980.9979787.

Burkart, J. M., S. B. Hrdy, and C. P. Van Schaik. 2009. Cooperative breeding and human cognitive evolution. Evolutionary Anthropoloov 18(5):175-86.

Butzer, Karl and Glynn Ll. Isaac. 1975. After the Australopithecines: Stratigraphy, ecology and culture change in the Middle Pleistocene. The Hague: Mouton.

Chazan, Michael. 2009. "Assessing the Lower to Middle Paleolithic transition," in Sourcebook of Paleolithic transitions. Edited by Martha Camps and Parth R. Chauhan, pp. 237-43. New York: Springer.

Chazan, Michael, and Liora Kolska Horoswitz, eds. 2007. Holon: A Lower Paleolithic site in Israel. Cambridge: Peabody Museum, Harvard University.

Clark, J. Desmond. 1967. The middle Acheulian site at Latamne, northern Syria. Quaternaria 9:1-68.

1969. The Middle Acheulian occupation site at Latamne northern Syria. Quaternaria 10:1-73.

Copeland, Lorraine, and Francis Hours. 1983. Le Yabroudien d'El Kowm et sa place dans le Paléolithique du Levant. Paléorient 9(1):21-37.

de Sousa, Alexandra, and Eugénia Cunha. 2012. "Hominins and the emergence of the modern human brain," in Progress in brain research, Vol. 195. Edited by M.A. Hofman and D. Falk, pp. 293-321. Amsterdam: Elsevier.

de Waal, Frans B. M. 2016. Are we smart enough to know how smart animals are? New York: W.W. Norton.

Domínguez-Rodrigo, Manuel, and Travis R. Pickering. 2003. Early hominid hunting and scavenging: A zooarcheological review. Evolutionary Anthropoloog 12(6):275-82.

Domínguez-Rodrigo, Manuel, H. T. Bunn, A. Mabulla, E. Baquedano, and T. R. Pickering. 2010. Paleoecology and hominin behavior during Bed I at Olduvai Gorge (Tanzania). Quaternary Research 74(3):301-3.

Domínguez-Rodrigo, Manuel, Rebeca Barba Egido, and Charles P Egeland. 2007. Deconstructing Olduvai: A taphonomic study of the Bed I sites. Dordrecht: Springer.

Dunbar, R. I. M. 2003. The social brain: Mind, language, and society in evolutionary perspective. Annual Review of Anthropoloog 32(1):163-81. 
Egeland, Charles P. 2008. Patterns of early hominid site use at Olduvai Gorge. Mitteilungen der Gesellschaft für Urgeschichte 17:9-37.

Egeland, Charles P., Travis Rayne Pickering, Manuel Domínguez-Rodrigo, and C. K. Brain. 2004. Disentangling Early Stone Age palimpsests: Determining the functional independence of hominid- and carnivore-derived portions of archaeofaunas. Lournal of Human Evolution 47(5):343-57.

Foley, Robert A. 1987. Another unique species: Patterns in human evolutionary ecology. London: Longman.

- 2001. "The evolutionary consequences of increased carnivory in hominids," in Meat eating and human evolution. Edited by Craig B. Stanford and Henry T. Bunn, pp. 305-31. Oxford: Oxford University Press.

Foley, Robert A., and Clive Gamble. 2009. The ecology of social transitions in human evolution. Philosophical Transactions of the Roval Societv B: Biological Sciences 364(1533):326779 .

Gamble, Clive. 1999. "The Hohlenstein-Stadel revisited," in The role of early humans in the accumulation of European Lower and Middle Palaeolithic bone assemblages. Edited by Sabine Gaudzinski, pp. 305-24. Mainz: Monographien des Römisch-Germanischen Zentralmuseums 42.

Gamble, Clive, and Wil Roebroeks. 1999. "The Middle Palaeolithic: A point of inflection," in The Middle Palaeolithic occupation of Europe. Edited by Wil Roebroeks and Clive Gamble, pp. 3-21. Leiden: Leiden University Press.

Garrard, Andrew N. 1983. "The Palaeolithic faunal remains from Adlun and their ecological context," in Adlun in the Stone Age: The excavations of D. A. E. Garrod in Lebanon, 19581963. Edited by Derek A. Roe, pp. 397-413. Oxford: British Archaeological Reports International Series.

Gaudzinski, Sabine. 1995. Wallertheim revisited: A re-analysis of the fauna from the Middle Palaeolithic site of Wallertheim (Rheinhessen/Germany). Lournal of Archaeological Science 22(1):51-66.

Gopher, Avi, Ran Barkai, Ron Shimelmitz, Muhamad Khalaily, Cristina Lemorini, Israel Heshkovitz, and Mary C. Stiner. 2005. Qesem Cave: An Amudian site in central Israel. Journal of the Israel Prehistoric Society 35:69-92.

Goren-Inbar, Naama, Nira Alperson, Mordechai E. Kislev, Orit Simchoni, Yoel Melamed, Adi Ben-Nun, and Ella Werker. 2004. Evidence of hominin control of fire at Gesher Benot Ya'aqov, Israel. Science 304(5671):725-27.

Goren-Inbar, Naama, Craig S. Feibel, Kenneth L. Verosub, Yoel Melamed, Mordechai E. Kislev, Eitan Tchernov, and Idit Saragusti. 2000. Pleistocene milestones on the out-of-Africa corridor at Gesher Benot Ya'aqov, Israel. Science 289:944-47.

Gowlett, John A.J. 2016. The discovery of fire by humans: A long and convoluted process. Philosophical Transactions of the Roval Societv B: Biological Sciences 371(1696): 20150164.

Gurven, Michael, and Kim R Hill. 2009. Why do men hunt? Current Anthropologv 50(1):5174.

Harvati, K. 2007. 100 years of Homo heidelbergensis—Life and times of a controversial taxon. Mitteilungen der Gesellschaft für Urgeschichte 16:85-94.

Hawkes, Kristen. 1991. Showing off: Tests of a hypothesis about men's foraging goals. Ethologv and Sociobiology 12(1):29-54. 
Hawkes, Kristen, and Rebecca Bliege-Bird. 2002. Showing off, handicap signaling, and the evolution of men's work. Evolutionary Anthropolooy 11(2):58-67.

Hrdy, Sarah B. 2007. "Evolutionary context of human development: The cooperative breeding model," in Family relationships: An evolutionary perspective. Edited by C.A. Salmon and T. K. Shackelford, pp. 39-68. Oxford: Oxford University Press.

Isaac, Glynn Ll. 1978. The food-sharing behavior of protohuman hominids. Scientific American 238(4):90-108.

1983. "Bones in contention: Competing explanations for the juxtaposition of early Pleistocene artifacts and faunal remains," in Animals and archaeology, vol. 1: Hunters and their prey. Edited by Juliet Clutton-Brock and Caroline Grigson, pp. 3-19. Oxford: British Archaeological Reports International Series.

Jelinek, Arthur J. 1982. The Tabun Cave and Paleolithic man in the Levant. Science 216:136975.

1990. "The Amudian in the context of the Mugharan tradition at the Tabun Cave (Mount Carmel), Israel," in The emergence of modern humans. Edited by Paul Mellars, pp. 81-89. Ithaka, NY: Cornell University Press.

Jelinek, Arthur J., William R. Farrand, Georg Haas, Aharon Horowitz, and Paul Goldberg. 1973. New excavations at the Tabun Cave, Mount Carmel, Israel, 1967-1972: A preliminary report. Paléorient 1(2):151-83.

Karkanas, Panagiotis, Ruth Shahack-Gross, Avner Ayalon, Miryam Bar-Matthews, Ran Barkai, Amos Frumkin, Avi Gopher, and Mary C. Stiner. 2007. Evidence for habitual use of fire at the end of the Lower Paleolithic: Site-formation processes at Qesem Cave, Israel. Iournal of Human Evolution 53(2):197-212.

Kramer, Karen L. 2005. Children's help and the pace of reproduction: Cooperative breeding in humans. Evolutionary Anthropoloogy 14(6):224-37.

Kuhn, Steven L., and Amy E. Clark. 2015. Artifact densities and assemblage formation: Evidence from Tabun Cave. Journal of Anthropolooical Archaeology 38:8-16.

Kuhn, Steven L., Ron Shimelmitz, and Amy E. Clark. 2018. "The road to differentiated land use and domestic space in the Middle Pleistocene of southwest Asia," in Crossing the human threshold: Dynamic transformation and persistent places. Edited by Matt Pope, John McNabb, and Clive Gamble, pp. 43-51. Abington, UK: Routledge.

Laland, Kevin N., F. John Odling-Smee, and Marcus W. Feldman. 2000. Niche construction, biological evolution, and cultural change. Behavioral and Brain Sciences 23(1):131-75.

Le Tensorer, Jean-Marie. 2005. Le Yabroudien et la transition du Paléolithique ancien au Paléolithique moyen en Syrie: L'exemple d' El Kowm. Munibe 57:71-82.

Lemorini, Cristina, Laurence Bourguignon, Andrea Zupancich, Avi Gopher, and Ran Barkai. 2016. A scraper's life history: Morpho-techno-functional and use-wear analysis of Quina and demi-Quina scrapers from Qesem Cave, Israel. Ouaternary International 398:86-93.

Lemorini, Cristina, Mary C. Stiner, Avi Gopher, Ron Shimelmitz, and Ran Barkai. 2006. Usewear analysis of an Amudian laminar assemblage from the Acheuleo-Yabrudian of Qesem Cave, Israel. Iournal of Archaeological Science 33(7):921-34.

Lovejoy, C. Owen. 1981. The origin of man. Science 211(4480):341-50.

Marder, Ofer, Gedalya Gvirtzman, Hagai Ron, Hamoudy Khalaily, Moshe Wieder, Rina Bankirer, Rivka Rabinovich, Naomi Porat, and Idit Saragusti. 1999. The Lower Paleolithic site of Revadim Quarry: Preliminary finds. Journal of the Israel Prehistoric Society 28:21-53. 
Marder, Ofer, Ariel Malinsky-Buller, Ruth Shahack-Gross, Oren Ackermann, Avner Ayalon, Miryam Bar-Matthews, Yonaton Goldsmith, Moshe Inbar, Rivka Rabinovich, and Erella H. Hovers. 2011. Archaeological horizons and fluvial processes at the Lower Paleolithic open-air site of Revadim (Israel). Lournal of Human Evolution 60(4):508-22.

Marder, Ofer, Ianir Milevski, Rivka Rabinovich, Oren Ackermann, Ruth Shahack-Gross, and Pinchas Fine. 2008. "The Lower Paleolithic site of Revadim Quarry, Israel," in Proceedings of the 5th International Congress on the Archaeology of the Ancient Near East. Edited by Joaquín Ma Córdoba, Miquel Molis, Ma Carmen Pérez, Isabel Rubio, and Sergio Martínez, pp. 481-90. Madrid: Centro Superior de Estudios sobre el Oriente Próximo y Egipto.

Marlowe, Frank W. 2003. A critical period for provisioning by Hadza men. Evolution and Human Behavior 24:217-29.

Meignen, Liliane, Ofer Bar-Yosef, John D. Speth, and Mary C. Stiner. 2006. Middle Paleolithic settlement patterns in the Levant," in Transitions before the Transition. Edited by E. Hovers and S. L. Kuhn, pp. 149-69. Boston: Springer.

Melamed, Yoel, Mordechai E. Kislev, Eli Geffen, Simcha Lev-Yadun, and Naama GorenInbar. 2016. The plant component of an Acheulian diet at Gesher Benot Ya'aqov, Israel. Proceedings of the National Academy of Sciences (USA) 113(51):14674-79.

Mounier, Aurélien, François Marchal, and Silvana Condemi. 2009. Is Homo heidelbergensis a distinct species? New insight on the Mauer mandible. Iournal of Human Evolution 56(3):219-46.

O'Connell, James F., Kristen Hawkes, Karen D. Lupo, and Nicholas G. Blurton Jones. 2002. Male strategies and Plio-Pleistocene archaeology. Iournal of Human Evolution 43(6):83172.

Odling-Smee, F. John, Kevin N. Laland, and Marcus W. Feldman. 2003. Niche construction: The neglected process in evolution. Princeton, NJ: Princeton University Press.

Pickering, Travis R. 2013. Rough and tumble: Aggression, hunting, and human evolution. Los Angles: University of California Press.

Plummer, Thomas W. 2004. Flaked stones and old bones: Biological and cultural evolution at the dawn of technology. American Journal of Physical Anthropoloov Suppl. 39:118-64.

Porat, Naomi, Li Ping Zhou, Michael Chazan, Tamar Noy, and Liora Kolska Horwitz. 1999. Dating the Lower Paleolithic open-air site of Holon, Israel by luminescence and ESR techniques. Quaternary Research 51(3):328-41.

Potts, Richard. 1984. Home bases and early hominids. American Scientist 72(4):338-47.

Preece, R. C., John A.J. Gowlett, Simon A. Parfitt, David R. Bridgland, and S. G. Lewis. 2006. Humans in the Hoxnian: Habitat, context and fire use at Beeches Pit, West Stow, Suffolk, UK. Iournal of Ouaternary Science 21(5):485-96.

Rightmire, G. Philip. 2003. Brain size and encephalization in Early to Mid-Pleistocene Homo. American Journal of Physical Anthropolooy 124(2):109-23.

Roebroeks, Wil, and Paola Villa. 2011. On the earliest evidence for habitual use of fire in Europe. Proceedinos of the National Academv of Sciences (USA) 108(13):5209-14.

Roebroeks, Wil, Mark J. Sier, Trine Kellberg Nielsen, Dimitri De Loecker, Josep Maria Parés, Charles E. S. Arps, and Herman J. Mücher. 2012. Use of red ochre by early Neandertals. Proceedinos of the National Academy of Sciences (USA) 109(6):1889-94.

Rolland, Nicolas. 2000. Cave occupation, fire-making, hominid/carnivore coevolution, and Middle Pleistocene emergence of home-base settlement systems. Acta Anthropologica Sinica 19(suppl.):209-17. 
2004. Was the emergence of home bases and domestic fire a punctuated event? A review of the Middle Pleistocene record in Eurasia. Asian Perspectives 43(2):248-80.

Rose, Lisa, and Fiona Marshall. 1996. Meat eating, hominid sociality, and home bases revisited. Current Anthropoloov 37(2):307-38.

Rust, Alfred. 1950. Die Hohlenfunde von Jabrud (Syrien). Neumunster: Karl Wachhotlz.

Schick, Kathy D. 1987. Modeling the formation of Early Stone Age artifact concentrations. Iournal of Human Evolution 16(7):789-807.

Seed, Amanda, and Richard Byrne. 2010. Animal tool-use. Current Biology 20:1032-39.

Shahack-Gross, Ruth, Francesco Berna, Panagiotis Karkanas, Cristina Lemorini, Avi Gopher, and Ran Barkai. 2014. Evidence for the repeated use of a central hearth at Middle Pleistocene (300ky ago) Qesem Cave, Israel. Lournal of Archaeological Science 44:12-21.

Sharon, Gonen. 2014. "The early prehistory of Western and Central Asia," in Cambridge world prehistory. Edited by Colin Renfrew and Paul Bahn, pp. 1357-78. Cambridge: Cambridge University Press.

Shimelmitz, Ron, and Steven L. Kuhn. 2017. "Shifting understandings of the AcheuloYabrudian complex and the Lower to Middle Paleolithic transition at Tabun Cave," in Vocation préhistoire hommage à Jean-Marie Le Tensorer. Edited by D. Wojtczak, M. Al Najjar, R. Jagher, H. Elsuede, F. Wegmüller, and M. Otte, pp. 343-53. Liège: ERAUL.

Shimelmitz, Ron, Michael S. Bisson, Mina Weinstein-Evron, and Steven L. Kuhn. 2017. Handaxe manufacture and re-sharpening throughout the Lower Paleolithic sequence of Tabun Cave. Quaternary International 428:118-31. doi:http://dx.doi.org/10.1016/j.quaint.2015 .12 .076 .

Shimelmitz, Ron, Steven L. Kuhn, Arthur J. Jelinek, Avraham Ronen, Amy E. Clark, and Mina Weinstein-Evron. 2014. "Fire at will": The emergence of habitual fire use 350,000 years ago. Journal of Human Evolution 77:196-203.

Shumaker, Robert W., Kristina R. Walkup, and Benjamin B. Beck. 2011. Animal tool behavior: The use and manufacture of tools by animals. Baltimore: Johns Hopkins University Press.

Solecki, Rose L., and Ralph S. Solecki. 1986. A reappraisal of Rust's cultural stratigraphy of Yabroud shelter I. Paléorient 12(1):53-59.

Solodenko, N., Andrea Zupancich, S. Nunziante Cesaro, Ofer Marder, Cristina Lemorini, and Ran Barkai. 2015. Fat residue and use-wear found on Acheulian biface and scraper associated with butchered elephant remains at the Site of Revadim, Israel. PLoS One. doi.org/10.1371 /journal.pone.0118572.

Speth, John D., and Jamie L. Clark. 2006. Hunting and overhunting in the Levantine late Middle Palaeolithic. Before Farming 3(1):1-42.

Stanford, Craig B. 1998. Chimpanzee and red colubus: The ecology of predator and prey. Cambridge: Harvard University Press.

Stiner, Mary C. 1990. The use of mortality patterns in archaeological studies of hominid predatory adaptations. Lournal of Anthropolooical Archaeology 9(4):305-51.

. 2002. Carnivory, coevolution, and the geographic spread of the genus Homo. Lournal of Archaeological Research 10(1):1-63.

2005. The faunas of Hayonim Cave, Israel. A 200,000-year record of Paleolithic diet, demography and society. American School of Prehistoric Research Bulletin 48. Cambridge: Peabody Museum, Harvard University. 
2013. An unshakable Middle Paleolithic? Trends versus conservatism in the predatory niche and their social ramifications. Current Anthropology 54(suppl. 8):s288-s304.

2017. Love and death in the Stone Age: What constitutes first evidence of mortuary treatment of the human body? Biolooical Theory 12(4):248-61.

Stiner, Mary C., and Steven L. Kuhn. 2016. Are we missing the "sweet spot" between optimality theory and niche construction theory in archaeology? Journal of Anthropological Archaeology 44 (part B):177-84.

Stiner, Mary C., Avi Gopher, and Ran Barkai. 2011. Hearth-side socioeconomics, hunting and paleoecology during the Late Lower Paleolithic at Qesem Cave, Israel. Lournal of Human Evolution 60(2):213-33.

Straus, Lawrence Guy. 1979. Caves: A palaeoanthropological resource. World Archaeology 10(3): $331-39$.

Stringer, Chris. 2012. The status of Homo heidelbergensis (Schoetensack 1908). Evolutionary Anthropoloog 21(3):101-7.

Tchernov, Eitan, Liora Kolska Horowitz, Avraham Ronen, and Adrian Lister. 1994. The faunal remains from Evron Quarry in relation to other Lower Paleolithic hominid sites in the southern Levant. Quaternary Research 42(3):328-39.

Teleki, Geza. 1973. The predatory behavior of wild chimpanzees. Cranbury, NJ: Bucknell University Press.

Tennie, Claudio, Robert C. O'Malley, and Ian C. Gilby. 2014. Why do chimpanzees hunt? Considering the benefits and costs of acquiring and consuming vertebrate versus invertebrate prey. Lournal of Human Evolution 71:38-45.

Tomasello, Michael. 2009. Why we cooperate. Cambridge: MIT Press.

Watts, Ian, Michael Chazan, and Jayne Wilkins. 2016. Early evidence for brilliant ritualized display: Specularite use in the Northern Cape (South Africa) between $\sim 500$ and $\sim 300 \mathrm{ka}$. Current Anthropolooy 57(3):287-310.

Weaver, Ann H. 2005. Reciprocal evolution of the cerebellum and neocortex in fossil humans. Proceedinos of the National Academv of Sciences (USA) 102(10):3576-80.

White, Mark J., and Nick Ashton. 2008. Lower Palaeolithic core technology and the origins of Levallois method in north-western Europe. Current Anthropology 44(4):589-609.

Wood, Brian M., and Ian C. Gilby. 2017. "From Pan to 'Man the Hunter': Hunting and meat sharing by chimpanzees, humans, and our common ancestor," in Chimpanzees and human evolution. Edited by Martin N. Muller, Richard W. Wrangham, and David Pilbeam, pp. 339-82. Cambridge: Harvard University Press.

Wrangham, Richard, and Rachel Carmody. 2010. Human adaptation to the control of fire. Evolutionary Anthropoloogy 19(5):187-99. 